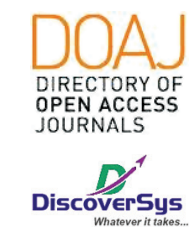

Published by DiscoverSys

\section{Karakteristik Penderita Kusta Multi Basiller (MB) dengan Reaksi Erythema Nodosum Leprosum (ENL) di Poliklinik Kulit dan Kelamin RSUP Sanglah selama Tahun 2016-2018}

CrossMark

\section{ABSTRACT}

Introduction: Leprosy is still a burden on endemic countries such as Indonesia. As well as leprosy reaction is a problem associated with the cessation of treatment from leprosy patients. The purpose of this study was to do a description of the characteristics of leprosy patients with ENL reactions in the Skin and Sex Polyclinic of Sanglah Hospital Denpasar.

Method: This study used a descriptive design with a retrospective approach conducted at the Skin and Sex Polyclinic of Sanglah General Hospital. A search related to the characteristics of leprosy patients who experienced an ENL reaction, then the data was presented in descriptive form.
Results: Female gender tend to have more severe leprosy reactions (50\%) compared to men. High income (50\%), non-endemic area origin (44.8\%), elementary school education level (44.4\%), and active working (31.0\%) tended to experience more severe leprosy reactions. And in this study more severe leprosy reactions were found in the multi-bacillary leprosy group (65.7\%), whereas mild leprosy reactions were higher in the pauci-bacillary leprosy group (34.2\%).

Conclusion: The high rate of severe leprosy reaction requires special attention from both the government and health practitioners, so that there is an integrated management of leprosy, so that the population in Indonesia becomes healthier.

Keywords: leprosy, reaction, prevalence, severity.

Cite This Article: Saraswati, P.A., Rusyati, L.M.M., Karmila, I.G.A.A.D. 2019. Karakteristik Penderita Kusta Multi Basiller (MB) dengan Reaksi Erythema Nodosum Leprosum (ENL) di Poliklinik Kulit dan Kelamin RSUP Sanglah selama Tahun 2016-2018. Intisari Sains Medis 10(3): 655-658. DOI: $10.15562 /$ ism.v10i3.477

\title{
ABSTRAK
}

Pendahuluan: Penyakit kusta masih menjadi beban bagi negara endemis seperti Indonesia. Serta reaksi kusta merupakan masalah yang dikaitkan dengan berhentinya pengobatan dari pasien kusta. Tujuan dari penelitian ini adalah untuk melakukan deskripsi terkait karakteristik pasien kusta dengan reaksi ENL di Poliklinik Kulit dan Kelamin RSUP Sanglah Denpasar.

Metode: Penelitian ini menggunakan rancangan deskriptif dengan pendekatan retrospektif yang dilakukan di Poliklinik Kulit dan Kelamin RSUP Sanglah. Dilakukan penelusuran terkait karakteristik dari pasien kusta yang mengalami reaksi ENL, kemudian data disajikan dalam bentuk deskriptif.
Hasil: Jenis kelamim perempuan cenderung lebih banyak memiliki reaksi kusta berat (50 \%) dibandingkan dengan laki-laki. Pendapatan mampu (50\%), asal daerah non-endemik (44,8\%), tingkatpendidikan sekolah dasar $(44,4 \%)$, dan status bekerja $(31,0 \%)$ cenderung lebih banyak mengalami reaksi kusta berat. Serta Pada penelitian ini lebih banyak ditemukan reaksi kusta berat pada kelompok kusta multi basiler $(65,7 \%)$, sedangkan reaksi kusta ringan lebih banyak pada kelompok kusta pausibasiler (34,2\%).

Simpulan: Masih tingginya angka reaksi kusta berat memerlukan perhatian khusus baik dari pemerintah maupun praktisi kesehatan, sehingga terdapat suatu manajemen terpadu terhadap penyakit kusta, sehingga populasi di Indonesia menjadi lebih sehat.
2Departemen/KSM $\quad$ IIm Kesehatan Kulit dan Kelamin, Fakultas Kedokteran, Universitas Udayana-RSUP Sanglah Denpasar, Bali-Indonesia

${ }^{*}$ Correspondence to: Putu Ayu Saraswati, Program Studi Pendidikan Dokter, Fakultas Kedokteran, Universitas Udayana ayusaraswatiff@gmail.com

Diterima: 05-04-2019

Disetujui: 11-04-2019

Diterbitkan: 01-12-2019

\section{Kata kunci: kusta, reaksi, prevalensi, tingkat keparahan.}

Cite Pasal Ini: Saraswati, P.A., Rusyati, L.M.M., Karmila, I.G.A.A.D. 2019. Karakteristik Penderita Kusta Multi Basiller (MB) dengan Reaksi Erythema Nodosum Leprosum (ENL) di Poliklinik Kulit dan Kelamin RSUP Sanglah selama Tahun 2016-2018. Intisari Sains Medis 10(3): 655-658. DOl: $10.15562 /$ ism.v10i3.477

\section{PENDAHULUAN}

Penyakit kusta sampai saat ini masih menjadi masalah kesehatan di Indonesia. Di saat jumlah penderita kusta di negara-negara lain sudah mulai berkurang, Indonesia justru menduduki urutan ketiga negara dengan reaksi kusta bastiler di dunia setelah India dan Brasil. World Health Organization 
(WHO) mencatat pada tahun 2014, sebanyak 213.899 penemuan kasus baru kusta terdeteksi di seluruh dunia dengan kasus tertinggi berada di regional Asia Tenggara yakni sebesar 154.834 kasus. ${ }^{1}$ Prevalensi kusta pada awal tahun 2015 didapatkan sebesar 0,31 per 100.000 penduduk. Kejadian Kusta masih sangat tinggi di beberapa negara, terutama negara berkembang yang sangat erat kaitannya dengan tingkat kemiskinan dan kepadatan penduduk. Indonesia merupakan negara tropis dan termasuk salah satu daerah endemik kusta Data Profil Kesehatan Republik Indonesia mencatat angka penemuan kasus baru kusta pada tahun 2013 sebanyak 16.856 kasus. $^{2}$

Penyakit kusta adalah penyakit kronis yang disebabkan oleh Mycobacterium leprae (M. leprae) yang pertama kali menyerang saraf tepi, selanjutnya dapat menyerang kulit, mukosa (mulut), saluran napas bagian atas, sistim retikuloendotelia, mata, otot, tulang dan testis. Untuk kepentingan pengobatan, World Health Organization (WHO) mengkasifikasikan kusta menjadi dua kelompok yaitu kusta multibasiler (MB) dan kusta pausibasiler (PB). Pada kusta pausibasiler, respon imun seuler berfungsi dengan baik, sedangkan pada kusta multibasiler imunitas seluler buruk sehingga gagal untuk melisiskan M. leprae. ${ }^{3}$

Kerusakan saraf atau kecacatan merupakan konsekuensi infeksi M. leprae pada penyakit kusta dimana 20-25\% penderita kusta dipastikan mengalami kecacatan. Kecacatan dapat dialami pada penderita dengan respon imun yang baik maupun yang buruk dimana kusta multibasiler memiliki resiko reaksi lebih tingggi dibandingan kusta pausibasiler. ${ }^{4}$ Kecacatan fisik permanen yang dialami oleh penderita kusta menimbulkan ketakutan dan stigma dari masyarakat yang menyebabkan berbagai dampak negatif dalam bidang psikososial maupun ekonomi bagi penderita, keluarga, dan orang-orang disekitarnya.

Pengobatan Kusta saat ini adalah menggunakan obat Multi Drug Treatment (MDT) yang merupakan regimen dari Rifampisin, Dapsone dan Clofazime untuk MB dan regimen Rifampisin dan Dapsone untuk PB. Pengobatan dilakukan selama 6-8 bulan untuk PB dan 12-16 bulan untuk MB dan dapat dikerjakan pada faskes tingkat pertama.

Reaksi kusta adalah episode akut dalam perjalanan kronis penyakit kusta yang berhubungan dan berlangsung sebelum, selama, atau sesudah pengobatan MDT. Reaksi kusta berhubungan dengan cedera saraf yang berat ditandai dengan hilangnya sensasi, paralisis, dan deformitas. ${ }^{5}$ Reaksi kusta merupakan keadaan darurat medik yang timbul pada $30-50 \%$ dari semua tipe kusta dan dibagi menjadi dua tipe, yakni reaksi kusta tipe 1 dan reaksi kusta tipe 2. Reaksi kusta tipe 1 merupakan akibat dari peningkatan imunitas seluler secara spontan, dimana mekanismenya belum dipahami secara keseluruhan. Sedangkan reaksi tipe 2 atau erythema nodosum leprosum (ENL) terjadi pada penderita kusta multibasiler, dengan imunitas seluler buruk terhadap $M$. leprae, dimana basil menjadi penuh dan menunjukkan respon antibodi monoklonal yang tinggi dan ditandai dengan tingginya immunoglobulin pada sirkulasi akibat antigen yang dihasilkan ketika M. leprae mati dalam jumlah yang tinggi.

Oleh karena itu, reaksi ENL yang dicetuskan dikaitkan reaksi hipersensitivitas tipe lambat. Sehingga pengobatan kusta ini sendiri juga harus berhati hati pada penderita yang mengalami kelainan autoimun seperti pasien dengan lupus, rematoid dan lain lain. Pasien biasanya akan datang kembali dan mengeluh kulit kemerahan, nyeri di tangan dan tungkainya. Hal ini juga akan berakibat pada ketidakpatuhan pasien dalam pengobatan sehingga akan memperparahan progresivitas penyakitnya.

Maka dari itu, karena tingginya angka penyakit kusta, karena kurangnya perhatian dalam pengobatan penderita kusta multibasiler dengan reaksi ENL dan mengingat adanya berbagai dampak negatif yang dirasakan penderita kusta dan keluarganya, maka diperlukan pemahaman yang menyeluruh dan pengetahuan mengenai karakteristik penderita MB terutama dengan reaksi ENL, sehingga dapat dilaksanakan penanganan yang tepat untuk mengurangi morbiditas dan memperbaiki prognosis penyakit.

\section{METODE}

Jenis penelitian ini adalah penelitian deskriptif dengan pendekatan retrospective. Pengumpulan data pada penelitian ini berupa data sekunder melalui rekam medis tahun 2017-2019 dengan data berupa riwayat sosial-ekonomi, demografi dan riwayat penyakit. Penelitian akan dilakukan di Poliklinik Kulit dan Kelamin Rumah Sakit Umum Pusat (RSUP) Sanglah. Analisis data dalam penelitian ini menggunakan bantuan SPSS versi 18.0 kemudian dilakukan analisis secara deskriptif.

\section{HASIL}

Sebanyak 35 orang sampel dipilih menggunakan total sampling dari data pasien kontrol/baru Morbus Hansen Poli Kulit RSUP Sanglah Tahun 2017-2019. Hal ini telah sesuai dengan kriteria minimal sampel yang diperlukan dalam penelitian ini, yaitu 35 orang. Tabel 1 memperlihatkan karakteristik sampel yang diperoleh pada penelitian ini. 
Tabel 1 Karakteristik Sampel

\begin{tabular}{lcc}
\hline Karakteristik & N & Proporsi (\%) \\
\hline Jenis kelamin & 24 & \\
$\quad$ Laki-laki & 11 & $68,6 \%$ \\
$\quad$ Perempuan & & $31,4 \%$ \\
Pendapatan & 16 & \\
$\quad$ Mampu & 19 & $45,7 \%$ \\
Tidak Mampu & & $54,3 \%$ \\
Asal Daerah & 6 & \\
Endemik & 29 & $17,1 \%$ \\
Non-Endemik & & $82,9 \%$ \\
Tingkat Pendidikan & 18 & \\
SD & 4 & $51,4 \%$ \\
SMP & 6 & $11,4 \%$ \\
SMA & 7 & $17,1 \%$ \\
S1 & & $20 \%$ \\
Pekerjaan & 29 & $82,9 \%$ \\
Bekerja & 6 & $17,1 \%$ \\
Tidak Bekerja & & \\
\hline
\end{tabular}

Tabel 2 Gambaran reaksi kusta terhadap jenis kusta

\begin{tabular}{lccc}
\hline & \multicolumn{2}{c}{ Jenis Kusta } & \\
\cline { 2 - 3 } & Ringan & Berat & Proporsi (\%) \\
\hline Jenis Kusta & & & \\
Multi Basiler & 11 & 12 & $65,7 \%$ \\
Pausibasiler & 9 & 3 & $34,2 \%$ \\
\hline
\end{tabular}

Tabel 3 Gambaran karakteristik sampel dengan reaksi kusta

\begin{tabular}{lcc}
\hline Karakteristik & Proporsi Jumlah (\%) & Proporsi Reaksi Kusta Berat(\%) \\
\hline Jenis kelamin & & \\
Laki-laki & $21(60 \%)$ & $8(38,3 \%)$ \\
Perempuan & $14(40 \%)$ & $7(50 \%)$ \\
Pendapatan & & $8(50 \%)$ \\
Mampu & $16(45,7 \%)$ & $7(36,8 \%)$ \\
Tidak Mampu & $19(54,3 \%)$ & $2(33,3 \%)$ \\
Asal Daerah & & $13(44,8 \%)$ \\
Endemik & $6(17,1 \%)$ & \\
Non-Endemik & $29(82,9 \%)$ & $8(44,4 \%)$ \\
Tingkat Pendidikan & & $3(42,9 \%)$ \\
SD & $18(51,4 \%)$ & $2(33 \%)$ \\
SMP & $4(11,4 \%)$ & $3(42,9 \%)$ \\
SMA & $6(7,1 \%)$ & $9(31,0 \%)$ \\
S1 & $7(20 \%)$ & $2(33,3 \%)$ \\
Pekerjaan & &
\end{tabular}

Reaksi Kusta yang berkaitan dengan jenis kusta pada penelitian ini merupakan gambaran perkembangan reaksi kusta pada daerah Bali khususnya yang pernah berobat ke RSUP Sanglah. Jenis Kusta didapatkan dengan mengkonversi Lepomatous (LL), Borderline (BL) dan MidBorderline (BB) menjadi Multibasiler sedangkan TT (Tuberkuloid), BT dan Intermediate digolongkan menjadi Pausibasiler. Pada penelitian ini lebih banyak ditemukan reaksi kusta berat pada kelompok kusta multi basiler $(65,7 \%)$, sedangkan reaksi kusta ringan lebih banyak pada kelompok kusta pausibasiler (34,2\%) (Tabel 2).

Karakteristik yang telah ditetapkan pada penelitian ini telah mengandung arti secara teori sehingga peneliti ingin mencari apakah faktor faktor karakteristik tersebut mempengaruhi reaksi kusta itu sendiri. Namun pada tabel penulis hanya menampilkan reaksi kusta yang berat yang ditampilkan dalam proporsi. Jenis kelamim perempuan cenderung lebih banyak memiliki reaksi kusta berat dibandingkan dengan laki-laki. Pendapatan mampu, asal daerah non-endemik, tingkat pendidikan sekolah dasar, dan status bekerja cenderung lebih banyak mengalami reaksi kusta berat (Tabel 3).

\section{PEMBAHASAN}

Subjek dari penelitian ini sebelumnya telah dipilih secara proporsional menggunakan total sampling pada Pasien baru/kontrol yang terdiagnosis kusta dengan reaksi ENL di Poliklinik Kulit dan Kelamin di RSUP Sanglah Tahun 2017-2019. Hal ini dimaksudkan agar sampel yang diambil dapat se-representatif mungkin dengan populasi target dari penelitian ini, yaitu pasien baru/kontrol MH di RSUP Sanglah.

Persebaran frekuensi antara sampel di jenis kelamin dan jumlah pendapatan tidak jauh berbeda $(10 \%-20 \%)$. Sedangkan pada asal daerah non-endemik memiliki proporsi besar karena pada saat proses sampling jumlah pasien baru/kontrol yang datang ke RSUP Sanglah dibandingankan yang Endemik cukup signifikan. Hal ini dapat dipengaruhi oleh jauhnya fasilitas RSUP Sanglah dari daerah endemik di Bali karena memakan waktu sekurangnya 2 jam untuk mencapai RSUP Sanglah. Namun penulis pikir perbedaan proporsi ini adalah wajar dikarenakan RSUP Sanglah merupakan pusat rujukan seluruh fasilitas kesehatan di Bali sehingga tidak akan merubah secara signifikan sampel secara keseluruhan.

Persebaran sampel pada Tabel 5. 2 di penelitian ini menunjukkan bahwa jumlah pasien yang terdiagnosis $\mathrm{MH}$ MultiBasiler lebih cenderung mengalami reaksi kusta berat atau reaksi ENL (>50\%). Sesuai dengan teori Ridley (1983) yang menjelaskan Reaksi ENL lebih sering pada BL dan 
LL sedangkan reaksi kusta ringan atau reaksi reversal lebih sering terjadi pada BT, BB dan BL. ${ }^{6,7}$

Penelitian ini menggunakan rekam medis sebagai konsep utama dalam mendata sampel dengan populasi target yaitu pasien $\mathrm{MH}$ baru/ kontrol RSUP Sanglah Tahun 2017-2019. Terdapat sekitar 50-60 pasien kontrol dan 2-3 pasien baru setiap bulannya dengan total sekitar 800 kunjungan disetiap tahunnya. Peneliti tidak memiliki data yang pasti dikarenakan keterbatasan waktu dalam mencari informasi rekam medis. Hal ini mengakibatkan penulis tidak memiliki total jumlah secara pasien MH di RSUP Sanglah dan tidak dapat menentukan prevalensi pasien $\mathrm{MH}$ baru/kontrol yang mengalami reaksi kusta.

\section{SIMPULAN}

Pada pasien kusta di Poliklinik Kulit dan Kelamin RSUP Sanglah Denpasar menunjukkan jenis kelamim perempuan cenderung lebih banyak memiliki reaksi kusta berat dibandingkan dengan laki-laki. Pendapatan mampu, asal daerah non-endemik, tingkat pendidikan sekolah dasar, dan status bekerja cenderung lebih banyak mengalami reaksi kusta berat.

\section{KONFLIK KEPENTINGAN}

Penulis menyatakan tidak terdapat adanya konflik kepentingan terkait publikasi dari artikel ini.

\section{PENDANAAN}

Penelitian ini tidak mendapat pendanaan dari pemerintah ataupun sector swasta lainnya.

\section{DAFTAR PUSTAKA}

1. WHO. Weekly epidemiological record 4 September 2015 [Internet]. Geneva: WHO [Dikutip 20 November 2015]. Tersedia di http://www.who.int/wer.

2. Departemen Kesehatan RI. Buku pedoman nasional pengendalian penyakit kusta. Jakarta :Depkes RI; 2007.

3. Attia EAS, Abdallah M, Saad AA, Afifi A, Tabbakh AE, El-Shennawy D, Hala D. Circulating CD 4+CD25highFoxP3+T autocrine/paracrine mechanism. J Immunol. 2010;151:979-89

4. Srinivasan H. Disability, deformity, and rehabilitation. In: Hastings RC, Opromollau DVA, editor. Leprosy. $2^{\text {nd }}$. London: Churchill Livingstone; 1994. p. 51-52.

5. Kumar A, Regi SR, Vaishnav K. A study of clinic-histopathological correlation of leprosy in tertiary hospital in western district of Rajasthan. 2014;2(3):43-48.

6. Ridley MJ, Ridlet DS. The immunopathology of erithema nodosum leprosum: the role of extravascular complexes. Lepr Rev. 1983;54(2):95-107.

7. Listiawan M. Comparison of TLR2/1, NF-кB p105/50, NF-KB p65, and TNF- $\alpha$ expressions in the macrophages between multibacillary leprosy patients with and without erythema nodosum leprosum signifying innate immune system activity. Bali Medical Journal. 2019;8(1):347-353. DOI:10.15562/bmj.v8i1.1482

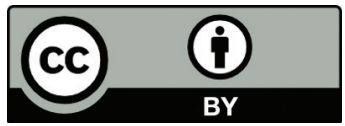

This work is licensed under a Creative Commons Attribution 